\title{
Selection objectives and criteria for sheep in Central Brazil
}

\author{
Concepta McManus ${ }^{1,2}$, Bruno Freitas Pinto $^{1}$, Rafhael Felipe Saraiva Martins ${ }^{1}$, Helder \\ Louvandini ${ }^{3}$, Samuel Rezende Paiva ${ }^{4}$, José Braccini Neto ${ }^{2}$, Tiago do Prado Paim ${ }^{1}$
}

\footnotetext{
${ }^{1}$ Faculdade de Agronomia e Medicina Veterinária, Universidade de Brasília, Brasília, DF, Brazil, 70910-900.

2 Departamento de Zootecnia, Faculdade de Agronomia, Universidade Federal do Rio Grande do Sul. Av. Bento Gonçalves, 7712 , Porto Alegre, RS, Brazil, 91540-000.

${ }^{3}$ Centro de Energia Nuclear na Agricultura/USP, Caixa Postal 96, Av. Centenário, 303, Piracicaba, SP, Brazil, 13400-970.

${ }^{4}$ EMBRAPA Recursos Genéticos e Biotecnologia, Asa Norte, Brasília, DF, Brazil, 70770-900.
}

\begin{abstract}
Three production systems for sheep (Low - L, Medium - M and High - H technology), with increasing technological levels, were studied under conditions in the Center-west of Brazil, to determine economic weights and selection indices of important traits. Receipts and costs were simulated using an economic simulator to calculate the structure of the operational costs. Only characteristics that were responsible for more than $10 \%$ of the profit were studied, which included: number of weaned lambs, food consumption (ewe and lamb), weight of carcass and weight of female lambs sold for reproduction. Regardless of the index used (profitability or yield) or system ( $\mathrm{L}, \mathrm{M}$ or $\mathrm{H}$ ), the economic weights are larger for the number of lambs weaned per ewe. With improvement in the technology used within the production system ( $\mathrm{H}$ to $\mathrm{L}$ ) the importance of this trait becomes less important. Lamb growth increased and weight of female for slaughter decreased in importance in higher technology systems. Changes in herd structure had little influence on economic values, whereas (co)variances were important sources of change in selection indices.
\end{abstract}

Key Words: correlations, costs, heritability, profit, revenue

\section{Introduction}

Lamb production in the tropics is based mainly on naturalised breeds both pure and crossbred with terminal sires (McManus et al., 2010), and the use of objectives and indices for selection is rare. The profitability of any livestock enterprise affects both consumers as well as producers as production costs are reflected in sale price. In recent years, farm products have failed to increase in price as much as goods from other sectors of the economy. Consequently, inflation in the farm sector (as a result of increases in prices received for farm products and prices paid for inputs bought from other areas of the farm sector) is not as high as in other sectors. Farmers do not buy all their farm inputs solely from the farm sector, therefore giving rise to a 'price-cost squeeze' on farm profits (Dickerson, 1982). There is a need, therefore, to increase the efficiency of livestock production, to help farmers increase the gross margins of their enterprises.

The development of breeding programs to increase the efficiency of livestock production has been the subject of much research (Ponzoni \& Newman, 1989; Willham, 1988) and most authors agree about the need for a systematic approach to ensure that progress is optimal in the desired direction. Highly efficient selection for the wrong objective may be worse than no selection at all (James, 1982). For example, studies with cattle have shown that selection for production alone in dairy cattle causes negative effects on udder health (Heringstad et al., 2003) and reproductive performance (Veerkamp et al., 2001; Haile-Mariam et al., 2003; Kadarmideen et al., 2003). Genetic programs which aim to improve both production and health traits in sheep are used in New Zealand and Australia (Eady et al., 2003; Woolaston \& Baker, 1996) and are usually separate indices for maternal or paternal lines (Conington et al., 2006). Depending on the farm system, economic values (EV) for individual traits within a selection program may differ considerably as a result of differing productivity and the physical constraints of the farms themselves.

Animal breeding aims to breed future generations that are more efficient under the farm conditions and social circumstances than those on-farm at the present (Groen, 2000). The determination of economic values for production traits taking profitability and genetic (co)variances into consideration is limited in Brazil. The present study aims to investigate three production systems and determine selection objectives and criteria for each. 


\section{Material and Methods}

Three production based systems for sheep were studied to determine economic weights of important traits in three herd sizes: 250, 500 and 1000 ewes. The reference systems (Low - L, Medium - M, High - H) used were defined based on increasing technological level and defined with field data collection and validated through the panels with farmers and specialists (Table 1). In system L, breeding and lamb rearing was done entirely at pasture, with little technological input. Weaning was at 120 days and no breeding seasons were used. Pasture quality was low with unimproved Andropogon gayanus grass. In M, dams were reared on pasture, but receiving supplementation before lambing, and lambs received supplementation after weaning at 90 days of age. Improved pastures of Panicum sp. grass were used. In $\mathrm{H}$, all animals were confined, there were three breeding seasons in two years and all animals received supplementation. Forage was based on corn silage. In all cases slaughter weight was fixed at $30 \mathrm{~kg}$ of live weight. Farm types were simulated, based on performance data (Table 2) and using the Simulador Econômica de Produção de Ovinos (SEPOV) developed by Chess Agronegócios, Brasília-DF from which EV were determined. Local market prices were collected and production indices were evaluated from databases and research with local farmers.
The age distribution and flock structure of the herd was used in defining the breeding objectives so that the number of replacements needed per year, and the number of animals in all classes available for market each year were considered in the calculation of economic values. Production indices were defined and economic analyses were carried out considering each one of the reference systems based on a 1,000-ewe herd. EVs for goal traits were calculated at mean performance levels.

The receipts and costs were simulated using an economic simulator to calculate the structure of the operational costs. If those traits, which account for more than $10 \%$ of the gross margin (Pearson, 1982), are included in the objective, the traits which remain are: number of lambs weaned (NLW); feed consumption of ewes (eFC) and offspring (oFC); lamb growth rate (lGR), carcass weight of cull ewes (eCW) and male lambs (lCW) and liveweight of ewe lambs sold for breeding (eLW) (Table 3).

The influence of variation in prices paid on the final cost of the lamb was evaluated for several situations: All females sold for meat; Half females sold for reproduction (considering stable herd, discarding replacement animals) or $10 \%$ of females sold for meat, in herds with 250 or 500 dams.

The economic weight is the change in net return per unit change in a character. Income (I) and expense (E) can be combined in different ways to estimate the economic values of traits. The economic values are found by expressing

Table 1 - Definition of three production systems for reference population in sheep in the Federal District

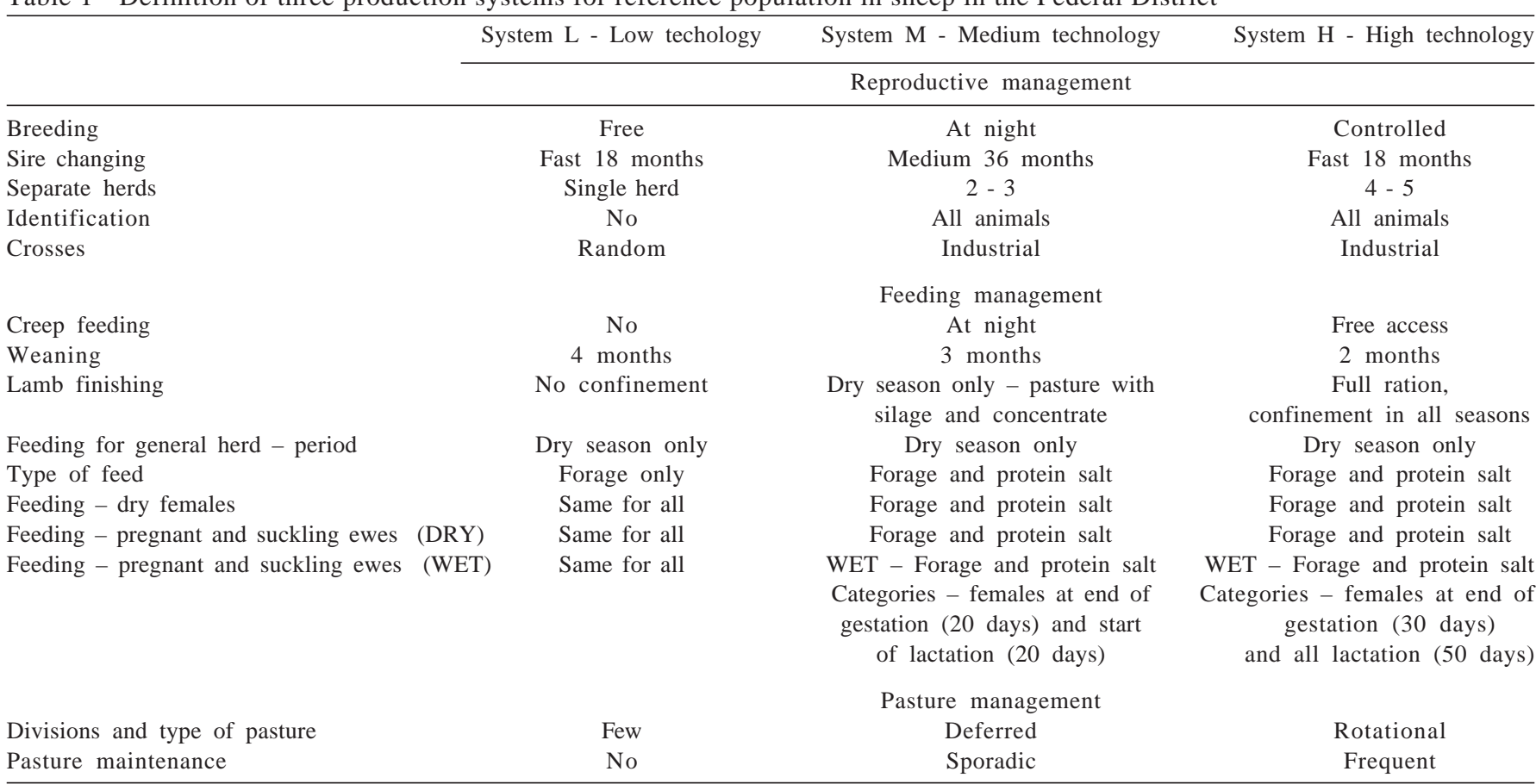


Table 2 - Technical indices for sheep herds in the Federal District, Brazil

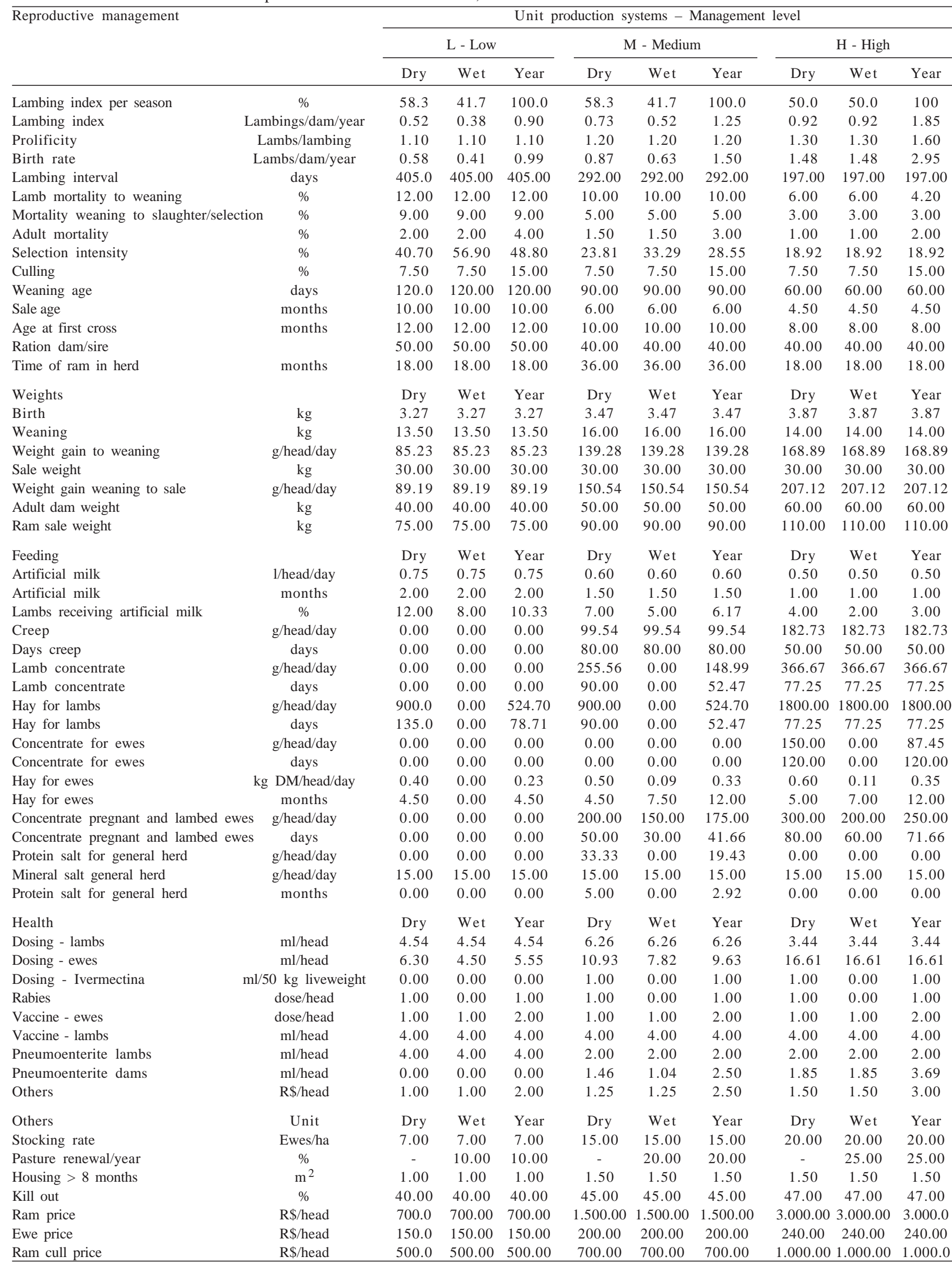


Profit (P) and liquid margins (LM) as a function of traits in the breeding objective and using partial differentiation of $\mathrm{P}$ and LM with respect to the trait in question (calculated at the average for all other traits). This has the effect of linearising the function. This is done on the grounds where genetic changes are slow and therefore, over a short period of time, will be essentially linear (James, 1986). Discounted gene flow was used to discount the future value of genetic improvement back to current prices (Hill, 1974).

A brief summary of index selection theory is given in James (1982). The phenotypic and genetic parameters used in this study are based on those estimated by Garcia et al. (2000); McManus \& Miranda (1998); Quesada et al. (2002); Lôbo et al. (2009a,b), Saramento et al. (2006), Sousa et al. (2006), Lôbo et al. (2006), Sousa et al., (1999), Carneiro et al. (2006), Souza et al. (2000), Silva \& Araújo (2000) and Sousa et al. (1999) for different production systems and levels of production (Table 4).
Information for selection comes from several sources (the individual, its sibs, the dam, sire and other relatives; Table 5).

Simulations were also carried out by increasing the number of observations by 10 and $20 \%$ and increasing and decreasing original heritability and correlation estimates by $50 \%$.

\section{Results and Discussion}

The economic analysis showed that the price currently paid to the consumer (R\$3.00/kg live weight), for system L is not viable economically for the farmer. When all females are sold for meat, the production cost is higher than the price paid for a 250-dam herd and the profit margin is very small in the other systems. Profit was higher when only a small portion of animals were sold for meat and replacement is from animals within the proper herd, thereby confirming the need for a well structured breeding program. All following simulations considered only a 500-head flock.

Table 3 - Sources of revenue and costs and traits involved in sheep production in the Midwest region of Brazil

\begin{tabular}{ll}
\hline Source of revenue and costs & \multicolumn{1}{c}{ Traits } \\
\hline $\begin{array}{l}\text { Revenue } \\
\text { Male lambs for slaughter }\end{array}$ & $\begin{array}{l}\text { Number of lambs weaned NLW (includes lambs born and lamb loss), lamb carcass weight LCW } \\
\text { Females for reproduction }\end{array}$ \\
Ewes for culling & $\begin{array}{l}\text { Mamber of lambs weaned NLW, Ewe lamb sale weight LCW } \\
\text { Cost }\end{array}$ \\
Feed (including land cost) & Number of lambs weaned NLW, feed consumption for adult ewes eFC and lambs lFC, lamb growth rate LGR \\
Buildings & Number of lambs weaned NLW \\
Labour & Number of lambs weaned NLW, disease resistance for ewes eDR and lambs lDR \\
Marketing & Number of lambs weaned NLW \\
Veterinary and health costs & disease resistance for ewes EDR and lambs LDR, number of lambs weaned NLW \\
\hline
\end{tabular}

Table 4 - Initial population parameters used to simulate selection criteria for sheep in the Federal District

\begin{tabular}{|c|c|c|c|c|c|c|}
\hline Trait & Units & $\begin{array}{c}\text { Phenotypic } \\
\text { standard deviation }\end{array}$ & Heritability & Repeatability & $\begin{array}{l}\text { Environment in } \\
\text { common for full sibs }\end{array}$ & $\begin{array}{l}\text { Economic } \\
\text { value }\end{array}$ \\
\hline & & \multicolumn{5}{|c|}{ Low technology system } \\
\hline Offspring food consumption & $\mathrm{kg}$ & 0.02 & 0.07 & 0.19 & 0.07 & 0.012 \\
\hline Lamb carcass weight & $\mathrm{kg}$ & 0.49 & 0.2 & 0.19 & 0.35 & 0.034 \\
\hline Ewe liveweight & $\mathrm{kg}$ & 0.42 & 0.2 & 0.02 & 0.58 & 0.029 \\
\hline Number of lambs weaned & head & 0.46 & 0.17 & 0.23 & 0 & 25.086 \\
\hline Lamb carcass weight & $\mathrm{kg}$ & 0.49 & 0.34 & 0.19 & 0.35 & 0.045 \\
\hline Ewe liveweight & $\mathrm{kg}$ & 0.42 & 0.22 & 0.2 & 0.58 & 0.01 \\
\hline \multicolumn{7}{|c|}{ High technology system } \\
\hline Offspring food consumption & $\mathrm{kg}$ & 0.02 & 0.56 & 0.19 & 0.07 & 0.008 \\
\hline Number of lambs weaned & head & 0.46 & 0.5 & 0.24 & 0 & 21.144 \\
\hline
\end{tabular}

Source: Garcia et. al. (2000); McManus \& Miranda (1998); Quesada et al. (2002); Silva \& Araújo (2000); Sousa et al. (1999). 
Table 5 - Number of observations for sheep production systems in Central Brazil

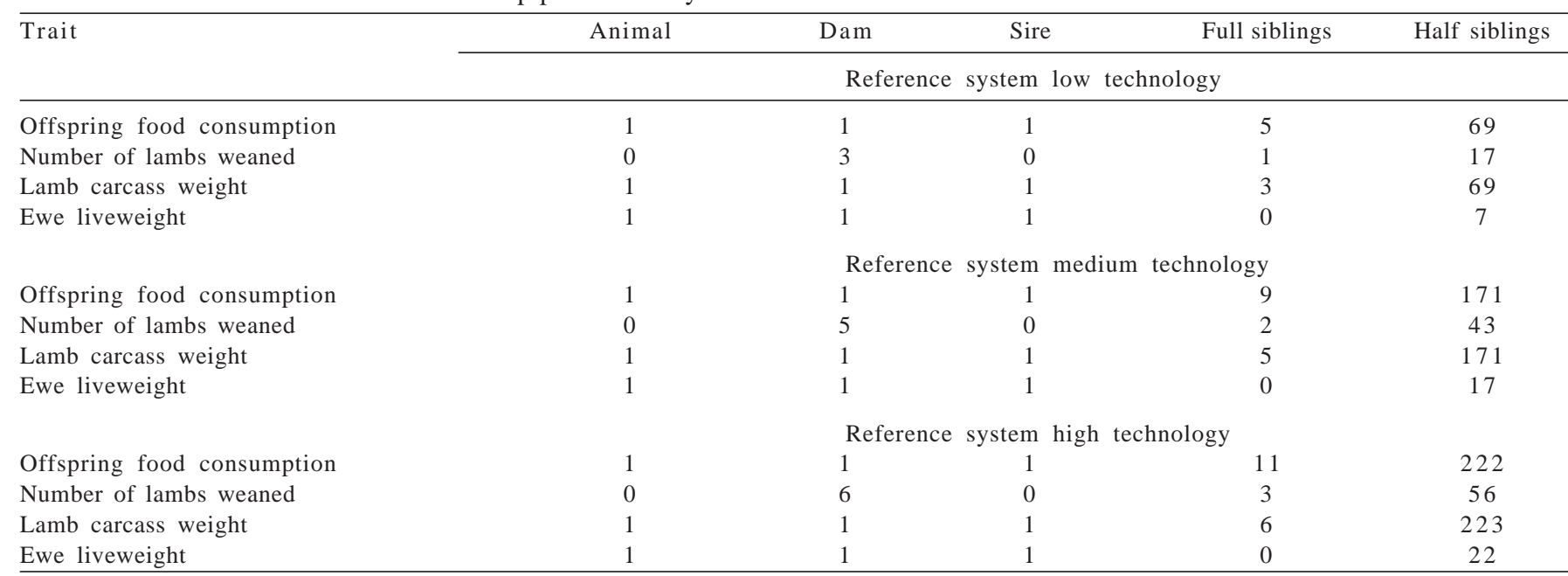

The demand for ewes is currently greater than the supply, affecting the price. In the Federal District, ewe lambs are marketed at approximately $\mathrm{R} \$ 180.00$ to $\mathrm{R} \$ 230.00$ while slaughter price is approximately $\mathrm{R} \$ 90.00$. Even poor quality animals with no breed characteristics are to be found at the price above. Compared with cattle production, the distortion in price is evident, as a Nellore heifer for reproduction is sold at a price close to slaughter price. The slaughter of female heifers is common when meat prices are higher than live female prices.

System H needed a 102-head flock to guarantee replacements while System M needs one with 145 animals. System $\mathrm{H}$ is therefore more efficient. For system M, Simulation 2 showed a $5 \%$ lower cost than simulation 1 , while this was $9 \%$ for System $H$. There is scale saving (approximately 20\% of the difference) as well as savings due to replacements with the proper herd.

Further simulations were carried out without using capital return, since frequently this is not used in agricultural projects (Table 4). In this case, the costs in Simulation 2 were 12.4\% lower than Simulation 1 for System M and 14.5\% lower for System $\mathrm{H}$. This is due to the lack of return in capital. The cost of production per kg was reduced in $\mathrm{R} \$ 1.00$ in $\mathrm{M}$ and $\mathrm{R} \$ 0.65 \mathrm{in} \mathrm{H}$.

The traits of economic importance found here are in agreement with Borg et al. (2007), Kosgey et al. (2004) and Wolfová et al. (2009) except for wool traits which are not important in this region of Brazil as generally sheep are not sheared. Most sheep selection indices involve wool traits, which make them difficult for comparison with data here.

Only the traits that were responsible for more than $10 \%$ of profit were considered for breeding purposes (Pearson, 1982). The traits considered included: number of lambs weaned; food consumption (dam and lamb); carcass weight (dam and lamb) and weight of female lambs sold for reproduction (Table 6).

Regardless of the method of calculation used (P or LM) or system studied ( $\mathrm{L}, \mathrm{M}$, or $\mathrm{H}$ ) the economic weights were higher for number of lambs weaned per dam. The better the management system ( $\mathrm{H}$ to $\mathrm{L}$ ) the less important this trait, and food consumption increased in importance. Mean slaughter weight of lambs had little influence on the economic weight. Profitability of system L was negative, meaning this system is highly inefficient for lamb production.

McManus \& Thompson (1993) showed similar results with red deer in England where a similar disequilibrium between females for reproduction and slaughter existed. Estimation of economic weights is difficult because prices vary periodically. The efficiency of an index is relatively robust for changes in economic weights. Rönningen (1971) concluded that loss in efficiency is not serious when moderate deviations from the true economic ratio are used.

Little difference ( $r>0.98)$ was found between using profit or liquid margin for calculating economic weights. Profit in the low technology system was negative. Number of lambs weaned (NLW) had the highest economic weight, in agreement with other studies (McManus \& Thompson, 1993). NLW is a direct response to many other traits, such as lamb mortality, as well as ewe fertility and prolificity. These traits were found by Lôbo et al. (2011) to have the highest economic value for Morada Nova sheep in Ceará State. Morais (2005) also found lamb survival to be the trait with highest economic value for Santa Ines sheep, but (Kosgey et al., 2004) found litter size and lambing frequency to be the most important traits, both having a direct effect on NLW. 
When (co)variances were taken into consideration, there was a change in the order of importance of the traits. For system A the most important trait was LCW, followed by LFC and eLW. For systems L and H, LCW was also the most important, followed by ILC and NLW. This is due to the already higher number of lambs weaned in these systems and the changes in heritabilities and correlations in these systems. An increase in the number of full or half sibs (10 or $20 \%$ ) also had little effect on the economic weights ( $r>0.99$ between these indices and original index). A decrease in $50 \%$ of the original heritabilities also affected the accuracy of the index in less than 10\% in System L, 12\% in system $\mathrm{M}$ and $7.6 \%$ in system $\mathrm{H}$. An increase in 50\% in initial parameter estimates led to an increase in accuracy of $9.2 \%$ in system L, 25\% in $\mathrm{M}$ and $29.8 \%$ in $\mathrm{H}$.
Economic weights (Table 7) are obtained by dividing the economic differences in Table 5 by the number of units of production for each trait. In this case, OFC and LCW used survival rates multiplied by the NLW for each system. ELW was 150 for each system.

System L had highest PECs for OFC and NLW. This is due to the use of higher technological levels (feeding, breeding, installations etc) resulting in higher number of lambs weaned, higher growth and survival rates, which directly affect economic weights. These herds also have lower genetic gain as they already have a higher level of production, so any small gain in economically important traits produces a significant gain in profit, especially comparing $\mathrm{M}$ with $\mathrm{L}$. The selection objevtives are therefore:

Table 6 - Economic values for production traits in sheep in three different production systems as described in the text

\begin{tabular}{|c|c|c|c|c|c|c|}
\hline System & & Initial level & Profit (R\$) & $\begin{array}{l}\text { Economic } \\
\text { differences }\end{array}$ & $\begin{array}{c}\text { Liquid } \\
\text { margin (R\$) }\end{array}$ & $\begin{array}{l}\text { Economic } \\
\text { differences }\end{array}$ \\
\hline \multirow{5}{*}{ Low } & Initial & & $-24,564.35$ & & $12,616.37$ & \\
\hline & Offspring food consumption & 87.63 & $-24,023.35$ & 541.01 & $13,158.11$ & 541.74 \\
\hline & Number of lambs weaned & 0.87 & $25,229.69$ & $49,794.05$ & $66,377.27$ & $53,760.90$ \\
\hline & Lamb carcass weight & 30.00 & $-22,790.56$ & $1,773.80$ & $14,392.57$ & $1,776.19$ \\
\hline & Ewe liveweight & 40.00 & $-24,383.41$ & 180.94 & $12,812.37$ & 196.00 \\
\hline \multirow{5}{*}{ Medium } & Initial & & $11,646.01$ & & $41,656.23$ & \\
\hline & Offspring food consumption & 145.00 & $12,226.82$ & 580.80 & $42,238.45$ & 582.22 \\
\hline & Number of lambs weaned & 1.35 & $70,597.89$ & $58,951.87$ & $102,737.10$ & $61,080.87$ \\
\hline & Lamb carcass weight & 30.00 & $14,785.49$ & $3,139.48$ & $44,803.34$ & $3,147.12$ \\
\hline & Ewe liveweight & 50.00 & $11,721.43$ & 75.42 & $41,753.53$ & 97.30 \\
\hline \multirow{5}{*}{ High } & Initial & & $21,427.59$ & & $55,194.57$ & \\
\hline & Offspring food consumption & 190.41 & $22,028.22$ & 600.62 & $55,797.40$ & 602.83 \\
\hline & Number of lambs weaned & 1.83 & $81,264.35$ & $59,836.76$ & $116,973.52$ & $61,778.95$ \\
\hline & Lamb carcass weight & 30.00 & $25,800.53$ & 4,372.94 & $59,583.58$ & 4,389.01 \\
\hline & Ewe liveweight & 60.00 & $21,565.77$ & 138.18 & $55,354.20$ & 159.63 \\
\hline
\end{tabular}

Table 7 - Economic weights for reference systems for sheep production in the Federal District

\begin{tabular}{|c|c|c|c|}
\hline \multirow[t]{2}{*}{ Trait } & Number for division (a) & Economic difference (b) & Economic weight (b/a) \\
\hline & \multicolumn{3}{|c|}{ System L } \\
\hline Offspring food consumption & $45,254.48$ & 541.01 & 0.012 \\
\hline Lamb carcass weight & $52,762.00$ & $1,773.80$ & 0.034 \\
\hline \multirow[t]{2}{*}{ Ewe liveweight } & $6,150.00$ & 180.94 & 0.029 \\
\hline & \multicolumn{3}{|c|}{ System M } \\
\hline Lamb carcass weight & $69,223.00$ & $3,139.48$ & 0.045 \\
\hline \multirow[t]{2}{*}{ Ewe liveweight } & $7,650.00$ & 75.42 & 0.010 \\
\hline & \multicolumn{3}{|c|}{ System $\mathrm{H}$} \\
\hline Offspring food consumption & $70,934.34$ & 600.62 & 0.008 \\
\hline Number of lambs weaned & $2,830.00$ & $59,836.76$ & 21.144 \\
\hline
\end{tabular}


System L: $\mathrm{OS}_{\mathrm{L}}=0.012(\mathrm{OFC})+26.628(\mathrm{NLW})+$ 0.034 (LCW)+0.029(ELW)

System M: $\mathrm{OS}_{\mathrm{M}}=0.010(\mathrm{OFC})+25.086(\mathrm{NLW})+$ 0.045(LCW)+0.010(ELW)

System $\mathrm{H} \mathrm{OS}_{\mathrm{H}}=0.008(\mathrm{OFC})+21.144(\mathrm{NLW})+$ 0.051(LCW)+0.015(ELW)

NLW was also found to be the most imporant trait in selction indices for Hungarian sheep (Komlósi et al., 2010). In Brazil, Morais (2005) and Lôbo et al. (2011) also showed the importance of preweaning traits in maintaining herd profits.
An increase of 10 or $20 \%$ in initial herd structure produced small changes in precision and standard deviation of the index (Table 8 ). A decrease in $50 \%$ of initial values (I-50\%) in heritabilities and correlations changed precision of System L in 10\%, less than 12\% in system $\mathrm{M}$ and $7.6 \%$ in System C. An increase in parameters in 50\% increased the precsion of System H in 9.2\%, 25\% in System M and 29.8\% in system $\mathrm{H}$. Genetic parameters are much more important than herd structure in terms of accuracy of the selection index.

Table 8 - Coefficients for selection criteria estimated for sheep production systems in the Fedral District of Brazil

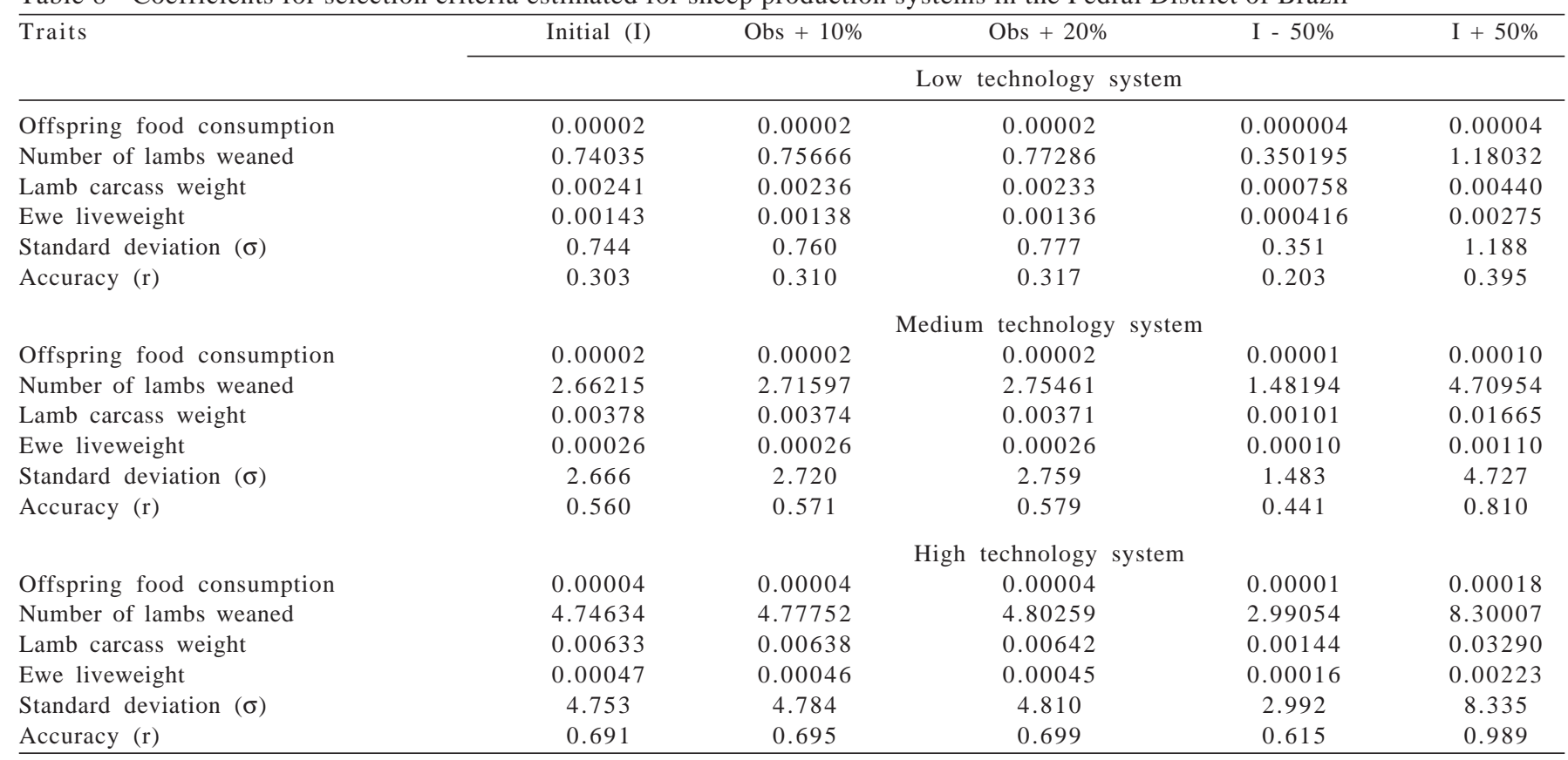

\section{Conclusions}

Sheep production in general is not economically viable in the region of Brasilia. Profit increased with technology level for sheep production systems in central Brazil. The number of lambs weaned had the highest economic value for all systems studied while changes in herd structure had little influence on economic values. Changes in (co)variances are important sources of change in selection indices and, care should be taken when estimating genetic parameters in different production systems.

\section{Acknowledgements}

INCT - Informação Genético-Sanitária da Pecuária Brasileira and FAPDF.

\section{References}

BORG, R.C.; NOTTER, D.R.; KUEHN, L.A. et al. Breeding objectives for Targhee sheep. Journal of Animal Science, v.85, p.2815-2829, 2007.

CARNEIRO, P.L.S.; AZEVEDO, D.M.M.R.; MALHADO, C.H.M. et al. Estudo de populações de ovinos Santa Inês utilizando técnicas de análise multivariada. Revista Científica de Produção Animal, v.8, p.38-48, 2006

CONINGTON, J. ; BISHOP, S.C.; LAMBE, N.R. et al. Testing selection indices for sustainable hill sheep production - lamb growth and carcass traits. Animal Science, v.82, p.445-453, 2006.

CONINGTON, J.; BISHOP, S.C.; WATERHOUSE, A. et al. A bioeconomic approach to derive economic values for pasturebred sheep genetic improvement programs Journal of Animal Science, v.82, p.1290-1304, 2004.

DICKERSON, D.E. Principles in establishing breeding objectives for livestock. In: WORLD CONGRESS ON SHEEP AND BEEF CATtle BREEDiNG, 1982, Madrid. Proceedings... Madrid: 1982. p.9-22. 
EADY S.J., WOOLASTON R.R., BARGER I.A. Comparison of genetic and nongenetic strategies for control of gastrointestinal nematodes of sheep. Livestock Production Science, v.81, n.1, p.11-23, 2003.

GARCIA, I.F.F.; PÉREZ, J.R.O.; TEIXEIRA, J.C. et al. Desempenho de cordeiros Texel x Bergamácia, Texel x Santa Inês e Santa Inês puros, terminados em confinamento, alimentados com casca de café como parte da dieta. Revista Brasileira de Zootecnia, v.29, p.564-572, 2000.

GROEN, A.F. Breeding goal definition. In: WORKSHOP ON DEVELOPING BREEDING STRATEGIES FOR LOWER INPUT ANIMAL PRODUCTION ENVIRONMENTS, 1999, Bella, Italy. Proceedings... Bella: 2000. p.25-104.

HAILE-MARIAM, M.; BOWMAN, P.J.; GODDARD, M.E. Genetic and environmental relationships among calving interval, survival, persistency of milk yield and somatic cell count in dairy cattle. Livestock Production Science, v.80, p.189-200, 2003.

HERINGSTAD, B.; CHANG, Y.M.; GIANOLA, D. et al. Genetic analysis of longitudinal trajectory of clinical mastitis in firstlactation Norwegian cattle. Journal of Dairy Science, v.86, p.2676-2683, 2003

HILL, W.G. Prediction and evaluation of response to selection with overlapping generations. Animal Production, v.18, p.117-140, 1974.

JAMES, J.W. Construction, uses and problems of multitrait selection indices. In: WORLD CONGRESS ON GENETICS APPLIED TO LIVESTOCK PRODUCTION, 2., 1982, Madrid. Proceedings... Madrid, 1982. p.130-139.

JAMES, J.W. Economic evaluation of breeding objectives in sheep and goats - general considerations. In: WORLD CONGRESS ON GENETIC APPLIED TO LIVESTOCK PRODUCTION, 3., 1986, Lincoln, Nebraska. Proceedings... Lincoln, 1986. p.470-478.

KADARMIDEEN, H. N., THOMPSON, R., COFFEY, M. P et al. Genetic parameters and evaluations from single- and multipletrait analysis of dairy cow fertility and milk production. Livestock Production Science, v.81, p.183-195, 2003.

KOMLÓSI, I.; SÁFÁR, L.; NAGY, I. et al. [2010] Selection indices for the Hungarian sheep population. Available at: <www.fao.org/regional/europe/PUB/RTS50/196.doc > Accessed on: Feb. 14, 2011

KOSGEY, I.S.; Van ARENDONK, J.A.M.; BAKER R.L. Developing breeding objectives for meat sheep in smallholder production systems in the tropics. Small Ruminant Research, v.88, p.143-160, 2004.

LÔBO, R.N.B.; VILLELA, L.C.V.; LÔBO, A.M.B.O. et al. Parâmetros genéticos de características estimadas da curva de crescimento de ovinos da raça Santa Inês. Revista Brasileira de Zootecnia, v.35, n.3, p.1012-1019, 2006

LÔBO, A.M.B.O.; LÔBO, R.N.B.; PAIVA, S.R. et al. Genetic parameters for growth, reproductive and maternal traits in a multibreed meat sheep population. Genetics and Molecular Biology, v.32, p.761-770, 2009a.

LÔBO, R.N.B.; VIEIRA, L.S.; OLIVEIRA, A.A. et al. Genetic parameters for fecal egg count, packed cell volume and body weight of Santa Inês Lambs. Genetics and Molecular Biology, v.32, p.288-294, 2009b.

LÔBO, R.N.B.; PEREIRA, I.D.C.; FACÓ, O. et al. Economic values for production traits of Morada Nova meat sheep in a pasture based production system in semi-arid Brazil. Small Ruminant Research, v.96, p.93-100, 2011.
McMANUS, C.; MIRANDA, R.M. Estimativas de parâmetros genéticos em ovinos Bergamacia. Revista Brasileira de Zootecnia, v.27, n.5, p.916-921, 1998.

MCMANUS, C.; THOMPSON, R. Breeding objectives for red deer. Animal Production, v.57, p.161-167, 1993.

MCMANUS, C.; PAIVA, S.R.; ARAUJO, R.O. Genetics and breeding of sheep in Brazil. Revista Brasileira de Zootecnia, v.39, p.236-246, 2010.

MORAIS, O.R. Valores econômicos para características de produção de ovinos Santa Inês. 2005. 50f. Tese (Doutorado em Ciências Animal) - Universidade Federal de Minas Gerais, Belo Horizonte.

PEARSON, R.E. Economic aspects of the choice of breeding objective. In: WORLD CONGRESS ON GENETIC APPLIED TO LIVESTOCK PRODUCTION, 2., Madrid, 1982. Proceedings... Madrid, 1982. v.2, p.50-59.

PONZONI, R.W.; NEWMAN, S. Developing breeding objectives for Australian beef cattle production. Animal Production, v.49, p.35-47, 1989.

QUESADA, M.; McMANUS, C.; D’ARAUJO COUTO, F.A. Efeitos genéticos e fenotípicos sobre características de produção e reprodução de ovinos deslanados no Distrito Federal. Revista Brasileira de Zootecnia, v.31, n.1, p.342-349, 2002 (supl.)

RÖNNINGEN, K. Some properties of the selection index derived by Henderson's Mixed Model Method. Acta Agriculturae Scandinavica, Section A - Animal Science, v.21, p.33-49, 1971.

SARMENTO, J.L.R.; TORRES, R.A.; SOUSA, W.H. et al. Estimação de parâmetros genéticos para características de crescimento de ovinos Santa Inês utilizando modelos uni e multicaracterística. Brazilian Journal of Veterinary and Animal Science, v.58, p.581-589, 2006

SILVA, F.L.R.; ARAÚJO, A.M. Características de reprodução e crescimento de ovinos mestiços Santa Inês, no Ceará. Revista Brasileira de Zootecnia, v.29, p.1712-1720, 2000.

SOUSA J.E.R. ; OLIVEIRA, S.M.P.; LIMA, F.A.M., et al. Efeitos genéticos e de ambiente para características de crescimento em ovinos Santa Inês no Estado do Ceará. Revista de Ciência Agronômica, v.37, p.364-368, 2006.

SOUSA, W.H.; PEREIRA, C.S.; BERGMANN, A.G. et al. Estimativas de componentes de (co)variânica e herdabilidade direta e materna de pesos corporais em ovinos da raça Santa Inês. Revista Brasileira de Zootecnia, v.28, p.1252-1262, 1999.

SOUZA, W.; PEREIRA, C.S.; BERGMANN, J.A.G. et al. Estimativa de componentes de variância e de parâmetros genéticos para características e reprodução por intermédio de modelos lineares e de limiar. Revista Brasileira de Zootecnia, v.29, n.6 (supl. 2), p.2237-2247, 2000

VEERKAMP, R.F., KOENEN, E.P.C.; JONG, G. Genetic correlations among body condition score, yield, and fertility in first-parity cows estimated by random regression models. Journal of Dairy Science, v.84, p.2327-2335, 2001.

WILLHAM, R.L. Selection objectives and programs applied to beef breeds in order to improve efficiency: North American example. In: WORLD CONGRESS ON GENETIC APPLIED TO LIVESTOCK PRODUCTION, 3., 1988, Paris. Proceedings... Paris, INRA, 1988. p.261-273.

WOLFOVA, M. ; WOLF, J.; MILERSKI, M. Calculating economic values for growth and functional traits in non-dairy sheep Journal of Animal Breeding and Genetics, v.126, p.480- 491, 2009.

WOOLASTON, R.R.; BAKER, R.L. Prospect of breeding small ruminants for resistance to internal parasites. International Journal for Parasitology, v.26, p.845-855, 1996. 